\section{Dental news}

\section{DEDICATION TO DENTAL INFORMATION AWARDED WITH MBE}

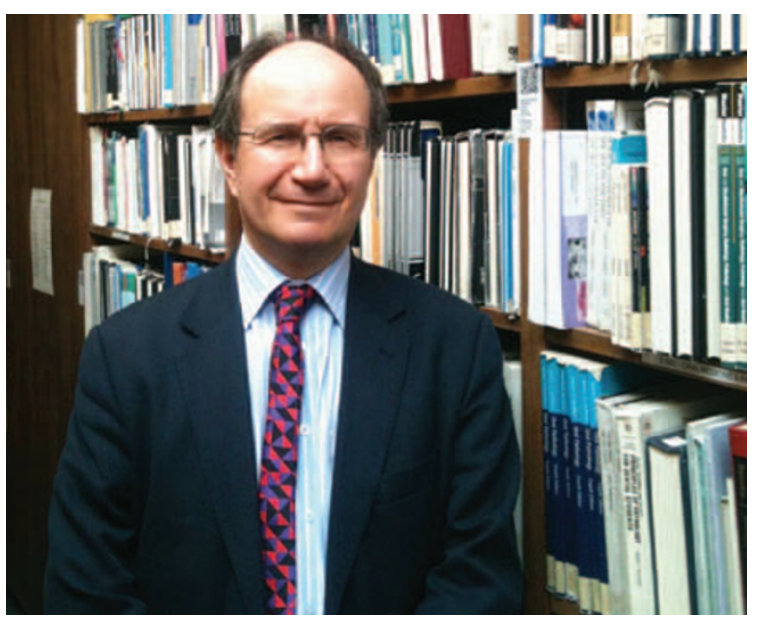

Roger Farbey, the British Dental Association's (BDA's) Head of Library \&t Knowledge Services, has been awarded the MBE in the Queen's Birthday Honours List. The MBE is for services to dentistry and dental information.

'I am naturally delighted with this honour but also regard it as recognition of the excellent staff that help run the BDA's Library, which is undoubtedly the best dental library in Europe,' said Roger as he was widely praised and congratulated by colleagues and on Twitter.

Roger has headed up the BDA Library since 1991 and was instrumental in computerising the Library's book collection, first using a system known as CALM and later by introducing the current Amlib system. This has enabled BDA members to use the Library's catalogue and library management system out-ofhours via the Internet.

Roger also introduced a free Medline searching service to members in 1991 which earlier this year was extended to give members the ability to access Medline (OVID) remotely from their own computers.

Roger is a Fellow of the Chartered Institute of Library \& Information Professionals, and has been actively promoting dental librarianship as Chair of the Dental Libraries Group and as a founder member of CHILL, the Consortium of Independent Health Information Libraries in London.
The BDJ News section accepts items that include general news, latest research and diary events that interest our readers. Press releases or articles may be edited, and should include a colour photograph if possible.

Please direct your correspondence to the News Editor, Kate Maynard at the BDJ, The Macmillan Building, 4 Crinan Street, London, N1 9XW or by email to k.maynard@nature.com

\title{
RESEARCHERS STUDY FOSSILISED PLAQUE
}

In a commentary for $\mathrm{CNN},{ }^{1}$ researcher Christina Warinner describes how she and a team of researchers from Switzerland, Denmark and Britain investigated a little-studied type of fossilised dental plaque as part of research into the origins and evolution of human disease.

As a molecular archaeologist, Dr Warinner conducts genetic research on the skeletal and mummified remains of ancient peoples, reconstructing the human genome at different times in the past and looking for differences that might be related to adaptations, risk factors, or inherited diseases.

According to the researchers, in eras before modern dentistry, as much as $600 \mathrm{mg}$ of calculus could build up on the teeth in a lifetime, compared to today's 10-30 mg per dental cleaning.

'Dental calculus fossilises just like the rest of the skeleton and can persist for tens of thousands of years,' said Dr Warinner.
Previously, microscopy studies had identified plant microfossils and an array of bacterial cells in ancient dental calculus. Taking this a step further, the researchers have now found that they can identify many bacterial species that inhabited the mouth and nasal passages of ancient humans, immunological proteins associated with inflammation and infection, and biomolecular indicators of foods that were consumed.

'We have also found bacteria that inhabit the lungs and gastrointestinal tract, thereby granting us virtual access to the previously inaccessible and long decomposed respiratory and digestive systems,' said Dr Warinner. 'Thus, the fossilised plaque can tell us about diet, immunity and pathogens not just in the mouth but throughout the body.'

The research is ongoing as the team continue to refine their methodology.

1. Warinner C. Why your dental plaque is valuable. 20 May 2012. http://edition.cnn. com/2012/05/20/opinion/warinner-dentalplaque/index.html (Accessed 22 May 2012).

\section{'TOOTH BUS' WILL OFFER FREE CHECK-UPS}

The NHS has commissioned a mobile dental unit, the Tooth Bus, offering anyone who has not seen an NHS dentist in the last two years a free dental examination. The bus will travel from Hampshire to Berkshire, then Oxfordshire and finally the Isle of Wight, finishing in May 2013. Patients will be able to book appointments on the Tooth Bus or just turn up. As well as providing free check-ups, the bus will educate communities on oral health and recommend patients to local practices.

The Tooth Bus aims to help rebuild relations between healthcare and the public by encouraging people to seek regular professional dental check-ups. www.toothbus.co.uk 